\title{
Implementation of Education Character to Overcome Students' Harvestion
}

\author{
A.Aco Agus ${ }^{1}$,Nur Qalbi ${ }^{2}$, Khaer Hanafie ${ }^{3}$,Muhammadong ${ }^{4}$ \\ 1,2,3,4 Universitas Negeri Makassar,Makassar, Indonesia \\ email:1*a.acoagus67@gmail.com
}

\begin{abstract}
Harassment among students are worrying phenomenon in the current digital era. Becausing the news spreads fast but does not create a deterrent effect for students especially at the junior high school level. This study aims to determine the forms of harassment that are common in the school environment, sanctions imposed on perpetrators and finally efforts to overcome harassment by the school. To achieve these objectives the researchers used a descriptive qualitative approach to change, explain the phenomenon of abuse that occurs among students in schools. Types of descriptive research are primary data sources namely informants consisting of school principals, teachers, and students. And the Secondary data is documents. Data collection techniques used were observation, interviews, and documentation. The data analysis technique used is descriptive qualitative. The results showed that there were many forms of violence which were commonly found by students in the school environment, both physical and psychological violence. Physical form includes, a) hitting, b) pinching, c) pressing down on the ear, and d) throwing using shoes. The form of psychological violence is giving harsh words. sanctions given by teachers for violence against students, namely: a) verbal reprimands, and b) written reprimands. The efforts made by teachers to overcome violence against students are: a) preventive measures (holding dialogue between teachers, parents, and students b) repressive actions by calling on school to avoid harassing student.
\end{abstract}

\section{Keywords-Harassment, Students, School environment}

\section{INTRODUCTION}

In essence, education has two goals, namely to help humans to be smart and encourage humans to become better. This means that intelligent people are easier than encouraging people to be better. Thus it can be said that moral problems are fundamental problems that fill human life whenever and wherever. Among students and moral damage are rife, deviant behavior, ethics, morals, and laws from mild to severe they often show [1]. One example at this time we often encounter acts of violence. This negative behavior shows the fragility of character in educational institutions in addition to due to environmental conditions that are not supportive .

\author{
IJoASER,Volume 3, Issue 1, March, 2020 \\ DOI: 10.33648/ijoaser.v2i2.41 \\ Copyriht: STAI Al-Furqan Makassar,Indonesia \\ Content License: CC-BY-SA
}

Received: 21 Jan |Revised: 15 Feb 2020 | Accepted: 02 March 2020 
This happens because formal education in Indonesia tends to be more oriented to education that is based on hard skills (technical skills), namely education that is more developed intelligence quotient (IQ), but less developed soft skills capabilities as contained in emotional intelligence (EQ), and spiritual intelligence [2]. As time goes by, education which is only based on hard skills is no longer relevant because sseornag's success in the future is not only determined by its hard skill performance but also its ability to develop soft skills.

Learning soft skills (social interaction) is very important in shaping the character of the nation's children so that they can compete, be ethical, moral, polite and interact with the community. Soft skill education is based on fostering mentality so that students can adjust to the realities of life. A person's success is not determined solely by knowledge and technical skills (hard skills), but also by the skills to manage themselves and others soft skills [3].

Character education which is one of the means of soft skills that can be integrated in learning in each subject. Learning materials related to norms or values in each subject need to be developed, made explicit, related to the context of daily life. [4]. Even every material in a subject needs to be integrated with character education. Thus, the learning of character values is not only at the cognitive level, but touches on internalization, and real practice in the lives of everyday students in the community [5].

This has become important, especially for students in Indonesia in recent decades [6]. Lately students have experienced a moral crisis. A crisis that attacks the younger generation, especially at school age. Indonesian youths are currently experiencing a crisis of morality and intellect on an alarming level.So that with character education students are expected to be able to interact according to customary and religious norms both within the school environment and in the community.

This study tries to describe the phenomenon of abuse that is rife among students and the efforts made by schools to overcome this. This research takes the subject of research in Makassar 35 Public Middle Schools in Makassar, students and teachers there help to explain the form of harassment that is common in their schools [7] 


\section{METHOD}

The research method used is a descriptive approach, this type of research is descriptive qualitative research that describes how harassment behavior occurs in the school environment and its handling efforts. The source of the data used are primary data by interviewing teachers and students, as well as secondary data from various literatures related to the theme of this study.

Data collection techniques include: Observation, Interview and Documentation. Data obtained from the results of the study were processed using descriptive qualitative data analysis.

\section{RESULTS}

Based on the results of the interview, researchers found out violence against students in the school environment. This is in line with the statement of the principal of Makassar 35 Public Middle School that triggers the occurrence of violence against students is the teacher is less able to control emotions. "Cause Teachers do violence because teachers are less able to control emotions whose names students sometimes act mischievously so that teachers who do not have patience then his emotions will peak ".

In internal conditions, so far there have been considerable gaps between efforts to advance education and the real conditions experienced in the field. This can be seen by the large number of teachers who commit violence and the lack of sanctions from the school. As for the violence that occurs in the school environment is physical violence and psychological violence:

\section{Physical Violence}

There are several definitions of the forms of violence that are explained in general in the Results of a Child Consultation on Violence against Children [8]. According to children, violence is an act that causes physical, psychological, or sexual harm. In this case it was further explained that physical violence included beatings with markers, pinching, pinching ears, and throwing with shoes.

\section{Psychic Violence}

Another form of violence is psychological violence experienced by students. Psychic violence is to say harsh words. This is in accordance with the statement of students named Helen Sinta Montong, Chair of Class VIII 5, namely:

"Teachers are used to hitting, like being swindled with harsh words, being pulled out of class and given standing in class, because students are naughty, rarely learn in class, take classes, don't do assignments or are included in BK."

Then reaffirmed by Ms. Nurmiati the Craft Teacher namely: 
"Honestly, I often give harsh words to students, for example at the time of the children's behavior test, spilling flour on the floor. Because I have already rebuked him to the point where harsh words or talk that make students angry are also angry, but there are also those who are only silent after being given a speech that makes them uncomfortable and there is also only laughter. Why did I do that, because the child had gone too far or the delinquency of the children was getting higher. So that I personally have too high emotions and run out of patience, then come out harsh words or talk that makes students angry or silent. "

Based on the results of one student's interview it can be understood that there were teachers who did psychological violence in which the teacher gave abusive words to students, then Helen Sinta Montong explained that: , did not hear what was said by the teacher but if it was repeated with harsh words my friend just relaxed not taken heart what the teacher said "

\section{Sanctions Given by Schools To Teachers Against Student Violence In Makassar 35 Public Middle School}

A teacher must approach gently and give praise to an educator rightly giving a good example to his students, because besides serving as an educator the teacher is the second parent for students. So, it is not appropriate for a teacher to commit violence against his students. However, it provides a punishment that has a red effect.

\section{Verbal Reprimand}

In giving sanctions to teachers who commit acts of violence against students, the Makassar 35 Public Middle School provides sanctions in the form of a warning in the form of a warning if the violence committed is still mild. This is in line with the statement of the principal of Makassar 35 Public Middle School which states that "teachers who commit violence are usually given a warning but if the violence goes beyond the limits, the school takes strict action against teachers who commit violence."

This was stated by Ibu Nurmiati, a teacher of the craft: "If there is a teacher who violates students who have exceeded the limit, the school gives a verbal warning, namely holding a meeting between the teachers. But as far as I know there is no verbal reprimand to teachers who commit violence because it might be considered to still not interfere with the child's mentality. And if there is then the school immediately takes action. It's just that we see what causes teachers to violence against students because of the behavior of these children who are no longer polite to the teacher. "

Oral reprimand given by the school against if violence occurs against students is to give a direct reprimand to the teacher concerned through a school meeting. This is done so that it can be a lesson for other teachers not to commit any acts of violence against students, both mild and severe violence.

\section{Written warning}

Teachers who commit acts of violence against their students should be given strict sanctions. The Makassar 35th Middle School has done that. If teachers who commit acts of violence against students have been given a verbal warning but still do the same thing then the teacher is given a written warning in the form of a warning 
letter. This is consistent with the statement made by Ibu Rosdiana, a BK teacher who said that "teachers who commit violence are given verbal reprimands, if they violate again then the school gives a written warning or if it can be submitted to the authorities.

\section{Preventive Action}

a) Hold dialogues between teachers, parents, and students

Efforts in creating a harmonious education without the element of violence are indeed not easy, given that there are currently many imbalances between internal conditions concerning systems and policies in educational institutions that are not in accordance with external conditions concerning the condition of teachers as part of the structure of an educational institution( concerning socio economic issues). So far the efforts undertaken by schools in creating education without violence are still limited to coaching and forming a forum for communication between teachers.

\section{b) Class discipline}

Another effort undertaken by the school in overcoming violence against students is by conducting socialization to students about the rules that apply in schools, the aim is to minimize the possibility of students violating the rules and regulations both inside and outside the classroom. this is done by the school to prevent acts of violence by teachers against students under the pretext of control. So far the efforts made by the Makassar 35 Public Middle School in preventing violence against students according to the head are "conveyed in a meeting, conveyed to the teacher so that violence does not happen again because the teacher is mature enough to take action and not repeat the same thing. This method is considered effective by the school to give advice to students as a whole.

\section{c) Moral Value Based Character Education}

Character education is the creation of a school environment that helps students in the development of ethics, responsibility through models, and teaching good character through universal values. These character values should be instilled in students so that they are able to apply in their lives both in the family, school, community, and country so that they can make a positive contribution to their environment. 


\section{DISCUSSION}

\section{Forms of Violence against Students in the School of Makassar 35 Public Middle School}

Physical violence that occurred in Makassar 35th Negri Middle School was throwing, hitting, pinching, and pressing or tweaking the ears. And these actions are a type of violence on students. But in SMP Negeri 35 the action is not to blame but to give a red effect to students and the consequences do not result in fractures, bruises, bleeding, or fainting.

This violence will affect the situation of feelings of insecurity and comfort, decreased self-esteem and dignity of the victim. At SMP Negeri 35 Makassar Psychic violence committed by teachers is by saying harsh words and embarrassing students in front of the class. This includes psychological violence. Pmicu, in some ways different from the conditions. Triggers are sourced directly from the case itself. Without triggers, violence will not appear, and nothing will happen between the perpetrator and the victim. The teacher commits violence against the students themselves who are the triggers so the teacher commits physical violence. Physical violence done by teachers is an act of violence that does not arise suddenly but, it happens because students do not do assignments or noisy in class. And students themselves should be more obedient to the rules of rules that apply in school, so that no teacher triggers violence against students in the school environment.

\section{Sanctions given by schools to teachers for student violence at SMP Negeri 35} Makassar

Punishment is actually a form of sanction given for violating applicable norms. Punishment is one of the tools in educating. In fact, physical punishment is used as a last alternative. Why? In my opinion, so that we have the opportunity to provide an explanation why students are punished. It could also be to relieve our anger so as to prevent us from acts of violence. Physical sanctions are given not to hurt because students are not controlled as well as the teacher's task is to find, observe and approach. Physical sanctions are given not to hurt, because they are now upside down not the teacher who hit but students, the cause is because the teacher and students are not controlled [8].

Teachers who commit violence are given a verbal warning, written and handed over to the authorities. So far the sanctions carried out by 35 Makassar Middle School schools [9]. If there is an act of violence between the teacher and the participant, the sanctions imposed by the school for teachers who commit acts of violence for education participants are given a warning barupa verbal reprimand, written, submitted legal trouble or submitted to the appropriate authorities. But so far there have been no cases of student violence perpetrated by teachers who have been involved in lawsuits. And so far the case has been resolved internally [10]. 
Although in the Act physical sanctions and psychological sanctions are legal or criminal sanctions, in the school can take a peaceful path in resolving these acts of violence. Because the consequences of the violence are not fatal enough and endanger students, both physically and psychologically. And in my opinion the action taken by the school and the teacher is the right thing and is a good step and away from the image of education which is always synonymous with violence.

\section{The efforts made by teachers in overcoming the Violence of Students in the Makassar 35th Middle School}

So far the efforts undertaken by schools in creating education without violence are still limited to coaching and forming a forum for communication between teachers. Not much effort has been made by the school in responding to problems related to violence by teachers against students, because the school considers that the problem can be solved amicably with the families of the students [11]. Until now the school still considers that cases of violence involving teachers as perpetrators as well as students who are victims are considered to be natural, and not a form of violence that must be dealt with seriously.

Another effort undertaken by the school is to establish a forum for socialization among internal parties of the school. In SMP Negeri 35 Makassar, socialization among internal parties of the school was conducted by holding a meeting. This socialization aims as a forum for teachers to create an atmosphere of mutual openness, and a place for teachers to try to discuss all matters relating to issues surrounding the teaching process, where the forum for meetings is only held once a month by the school. A very important effort is carried out maximally by the school is to form a place for routine socialization and communication with the parents of students. And so far the Makassar 35 Public Middle School has tried to establish good communication between teachers, parents, and students. And find out why students make mistakes at school that causes such.

This prevention effort is a unity with one another in overcoming violence, namely:

1) Preventive efforts are more emphasized on how to anticipate the potential for crime or close the perpetrators' room to commit crime If the effort is more incentive to reduce the intention to commit the crime itself. Even if there is an intention to do that if the opportunity does not exist then it will not happen. Occurs because of intentions and opportunities.

2) Repressive efforts where these efforts are made when they have occurred. Management with repressive efforts to act against the perpetrators in accordance with their actions and improve them again so that they are aware that the act that was done is harmful, so they do not repeat it again. In tackling repressively the methods adopted are no

IJoASER, Volume 3, Issue 1, March, 2020

DOI: 10.33648/ijoaser.v2i2.41

Copyriht: STAI AI-Furqan Makassar,Indonesia

Content License: CC-BY-SA

Received: 21 Jan |Revised: 15 Feb 2020 | Accepted: 02 March 2020 
longer at the stage of how to prevent tackling or find solutions to the crimes / violence that have occurred. On that basis, the steps taken tend to how to crack down on the perpetrators or how to give a red effect on the perpetrators.

In order to provide more comprehensive protection for school students who in this case are children, Law No. 23 of 2002 concerning Child Protection has also been regulated regarding the Indonesian Child Protection Commission in Chapter XI of this Law. As it is known, the Indonesian Child Protection Commission ( KPAI) is an independent institution whose position is on the same level as a State Commission formed based on the mandate of Presidential Decree Number 77 of 2003 and Article 74 of Law Number 23 of 2002 in order to improve the effectiveness of the implementation of child protection in Indonesia.

\section{Character education as an alternative to overcoming harassment}

Character education is a system of naming character values to school members which includes components of knowledge, awareness or willingness and actions to implement these values, both towards God Almighty, self, fellow human beings, the environment, and nationality so that they become human morality. In character education in schools, all components (stakeholders) must be involved, including the components of education itself, namely the curriculum, the learning process and assessment, the quality of relationships, the handling or management of subjects, school management, implementation of activities or co-curricular activities, empowerment facilities, infrastructure, financing, and the work ethic of all citizens and the school environment [12].

"Whole and comprehensive character education does not merely shape young people into smart and good personalities, but also shape them into good behavior for changes in social order to become more just, kind, and humane" .

Efforts to Overcome Violence (Bullying) through Character Education The following efforts can be made to overcome and overcome violence through character education: (1) strengthen social control, this can be interpreted as a variety of ways used by educators to discipline students who make storage, including the act of violence by conducting surveillance and enforcement; (2) developing a culture of asking and forgiving; (3) applying anti-violence principles; (4) providing peace education to young people; (5) enhance intensive dialogue and communication between students in schools; 


\section{CONCLUSION}

From the results of the research conducted it can be concluded that:

1. The forms of violence perpetrated by teachers in Makassar 35 Public Middle Schools are generally physical violence where the teacher hits, protrudes, boils ears, and throws shoes due to the students themselves making mistakes which is not listening when the teacher explains, and noisy in class. Whereas in the form of psychological violence is saying harsh words to students.

2. Sanctions given by Makassar 35 Public Middle School for teachers who commit acts of violence for students are given a warning in the form of verbal reprimands, and written reprimands.

3. Efforts to tackle the occurrence of acts of violence. 


\section{REFERENCES}

[1] Şahin, M. (2012). An investigation into the efficiency of empathy training program on preventing bullying in primary schools. Children and Youth Services Review, 34(7), 1325-1330. doi:10.1016/j.childyouth.2012.03.013

[2] Ttofi, M. M., \& Farrington, D. P. (2011). Effectiveness of school-based programs to reduce bullying: A systematic and meta-analytic review. Journal of Experimental Criminology, 7(1), 27-56. doi: 10.1007/s11292-010-9109-1

[3] Chui, W.H \& Chan, H.C.O (2015) Self-Control, School Buliying Perpetration, and Viticimization Among Macanese Adolescentts, Journal of Child and Family Studies , 24(6), 1751-1761.DOI: 10.1007/s108 26-014-9979-3.

[4] Healy, K.L., Sanders, M.R,.., \& Lyer, A. (2015). Parenting practices, children's peer relationships and being bullied at school. Journal of Child and Family Studies, 24(1), 127-140. DOI: 10.1007/ s10826-0139820-4.

[5] Beattie, R.M (2015). Long-term effect of bulliying. Archieve of Disease in Childood, 100(9i).

[6] Galtung, Johan. 1992. Kekuasaan danKekerasan. Yogyakarta:Kanisius. Maidin Gulton. 2018. Perlindungan Hukum terhadap Anak dan Perempuan. Cetakan Ke-4 Bandung : PT Refika Aditima.

[7] Golmaryami, F.N., Frick, P.J., Hemphill, S.A., Kahn, R.E., Crapanzano, A.M., \& Terranova, A.M. (2016). The Social, behavioral, and emotional correlates of bullying and victimization in a school-based sample. Journal of Abnormal Child Psychology, 44(2), 381-391. DOI: 10.1007/s10802-015-9994-x.

[8] Juminah, 2004Analisis Sosial-Yuridis terhadap Undang-Undang Nomor 23 Tahun 2002 Tentang perlindungan Anak di Kota Makassar

[9] Yustina, Saptarini, 2009. Kekerasan dalam lembaga Pendidikan Formal (Studi mengenai Kekerasan oleh Guru Sekolah terhadap Siswa Sekolah dasar di Surakarta)

[10] Nashriani. 2014. Perlindungan Hukum Pidana Bagi Anak di Indonesia. Cetakan Ke-3. Jakarta: Rajawali.

[11] Guerra, N.G., Kim, T.E., \& Sadek, S. (2010). Predictors of bullying and victimization in childhood and adolescence: A meta-analytic investigation. School Psychology Quarterly, 25(2), 65.

[12] Saiful, Bahri, 2015. Implementasi Pendidikan Karakter Dalam Mengatasi Krisis Moral Di Sekolah, Jurnal Ta'alum, Volume 03, NO 01 Bulan Juni 